\title{
Mortality and Marital Status
}

\author{
BY DEWEY SHURTLEFF, M.P.H.
}

\begin{abstract}
A NUMBER of analyses have shown that A married people live longer than single people. The most recent analysis published for the United States was for 1940 (1), and the figures clearly showed the lower mortality rates for the married population. In the years since 1940 , there has been a tremendous change in mortality rates and a distinct increase in the married proportion of the population. In the light of these changes, it is of particular interest to reexamine the mortality rates by marital status based on the 1950 census.
\end{abstract}

\section{Population Base}

In the 1950 census ( 2$)$, data on marital status were based on the replies to the question, "Is he (she) now married, widowed, divorced, separated, or has he never been married?" The question referred to status at the time of enumeration. Persons classified as married comprise, therefore, both those who have been married only once, those who remarried after having been widowed or divorced, and persons reported as separated. Those reported as never married or with annulled marriages were classified as single. Since it is probable that some divorced persons were reported as single, married, or widowed, the census returns doubtless

Mr. Shurtleff is an analytical statistician in the Mortality Analysis Section, National Office of Vital Statistics, Public Health Service. understated somewhat the actual number of divorced persons who have not remarried.

The distribution of the population by marital status for each age-sex group is shown in table 1. Most men were single at ages 20-24 years, but they soon got married; 3 out of 4 men were married at ages 25-29. Two out of three women were married by the time they were 20 $2 \pm$ years old, and at ages $25-29,4$ out of 5 were married. The peak percentage married was 87.1 for men at ages $40-44$ and 86.2 for women at $30-34$ years. From 35 years on for men and from 30 years on for women the single proportion of the population remained nearly constant, close to 10 percent. The proportion widowed increased with advancing age, much more so for women than for men. The peak percentage divorced was 3.0 for men at ages $50-54$ and 3.7 for women at $40-44$ years.

\section{Mortality Data}

Marital status at the time of death is reported routinely on the death certificate. Deaths classified in the same categories as the enumerated population are now available for 1949,1950 , and 1951 ; rates shown in this paper are based on the average annual number of deaths for these 3 years and on the population enumerated in the 1950 census.

The death rates are shown by marital status, age, and sex in table 2. To summarize, if the 1949-51 death rates for age 20 and over by marital status, age, and sex had occurred in a standard population distributed by age like the 
population for each sex enumerated in 1940 , taking the expected numbers of deaths for the married as 100 , the index numbers would be:

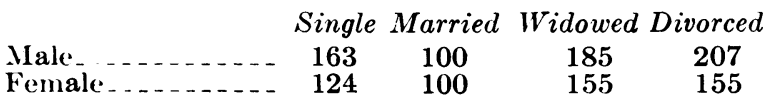

These figures summarize the mortality differences among the marital classes. The lowest mortality is still found for the married population, the next most favorable in the single group, and the highest among the widowed and divorced. The differences in mortality between the married and the unmarried are greater for men than for women.

\section{Mortality by Marital Status, Age, and Sex}

It is evident from table 2 that all through the age span, for men and for women, the death rates are lower for the married than for the single, widowed, or divorced. For both men and women in every age group 20 year's and over, the mortality rank-order of three of the marital classes generally remains the same: the lowest for the married, the next for the single, and the highest for the divorced. The rank-order of the widowed class shifts with advancing age. The death rate for widowers is the highest of the four marital classes at the early ages, but at ages beyond 60 years, the mortality of widowers is less than that of either single or divorced men. I similar pattern holds for women, although the death rates for widows do not fall below that of the divorced until after age 60 .

The differences in death rates may be due, in part, to the greater tendency of healthier people to marry. The evidence for selection as a factor in the differences in rates may be seen more clearly by examining the relative differences in rates between the unmarried and the married at each age. Taking the mortality of the married as 100 in each age group, the chart shows the age-specific death rates for the single, widowed, and divorced expressed as percentages of the corresponding rate for the married. The differences are the greatest between married and ummarried men between the ages of 25 and 44. Similarly, the differences between married and ummarried women are greatest between the ages of 25 and 34 . Beyond these ages the curves
Table 1. Percentage distribution of the population by marital status, according to age and sex: United States, 1950

\begin{tabular}{|c|c|c|c|c|}
\hline $\begin{array}{l}\text { Sex and age } \\
\text { (in years) }\end{array}$ & Single & Married & $\begin{array}{l}\text { Wid- } \\
\text { owed }\end{array}$ & Divorced \\
\hline \multicolumn{5}{|l|}{ Male } \\
\hline 20 and over $\ldots . .$. & 17. 0 & 76.1 & 4. 7 & 2. 2 \\
\hline $\begin{array}{l}20-24 \\
25-29 \\
30-34 \\
35-39 \\
40-44 \\
45-49\end{array}$ & \begin{tabular}{|r|}
59.1 \\
23.8 \\
13.2 \\
10.1 \\
9.0 \\
8.7
\end{tabular} & \begin{tabular}{l|l} 
39. 9 \\
74.2 \\
84.3 \\
86.8 \\
87.1 \\
86.2
\end{tabular} & $\begin{array}{r}.2 \\
.3 \\
.4 \\
.7 \\
1.2 \\
2.1\end{array}$ & $\begin{array}{l}.9 \\
1.7 \\
2.1 \\
2.4 \\
2.7 \\
2.9\end{array}$ \\
\hline $\begin{array}{l}50-54 \\
55-59 \\
60-64 \\
65-69 \\
70-74 \\
75 \text { and over }\end{array}$ & \begin{tabular}{l|l}
8.3 \\
8.3 \\
8.6 \\
8.7 \\
8.3 \\
7. 8
\end{tabular} & $\begin{array}{l}\text { 85. } 0 \\
83.1 \\
79.3 \\
74.0 \\
67.5 \\
52.4\end{array}$ & $\begin{array}{r}3.7 \\
5.9 \\
9.6 \\
15.0 \\
22.2 \\
38.5\end{array}$ & $\begin{array}{l}\text { 3. } 0 \\
2.7 \\
2.5 \\
2.3 \\
1.9 \\
1.3\end{array}$ \\
\hline \multicolumn{5}{|l|}{ Female } \\
\hline 20 and over... & 11.8 & 72.3 & 13. 3 & 2. 7 \\
\hline $\begin{array}{l}20-24 \ldots \ldots \\
25-29 \ldots \\
30-34 \ldots \ldots \\
35-39 \\
40-44 \ldots \\
45-49 \ldots\end{array}$ & \begin{tabular}{|r|}
32.3 \\
13.3 \\
9.3 \\
8.4 \\
8.3 \\
7.9
\end{tabular} & \begin{tabular}{l|}
65.6 \\
83.3 \\
86.2 \\
85.5 \\
83.1 \\
79.8
\end{tabular} & $\begin{array}{l}.4 \\
.9 \\
1.6 \\
2.7 \\
5.0 \\
8.6\end{array}$ & $\begin{array}{l}1.7 \\
2.5 \\
\text { 3. } 0 \\
\text { 3. } 5 \\
\text { 3. } 7 \\
\text { 3. } 6\end{array}$ \\
\hline $\begin{array}{l}50-54 \\
55-59 \\
60-64 \\
65-69 \\
70-74 \\
75 \text { and over }\end{array}$ & $\begin{array}{l}7.7 \\
7.7 \\
8.2 \\
8.4 \\
9.0 \\
9.5\end{array}$ & $\begin{array}{l}75.0 \\
69.1 \\
60.1 \\
48.9 \\
36.6 \\
18.7\end{array}$ & \begin{tabular}{l|}
13.9 \\
20.5 \\
29.7 \\
41.1 \\
53.3 \\
71.2
\end{tabular} & $\begin{array}{l}3.3 \\
2.7 \\
2.1 \\
1.5 \\
1.1 \\
.6\end{array}$ \\
\hline
\end{tabular}

SOURCE: Table 102 of reference 2.

show a tendency to converge, more so for women than for men. At the older ages there is less difference in mortality between the married and the unmarried. The chart also shows that differences in rates between the married and the unmarried, in each group, are greater for men than for women.

The persistent differences in rates between the married and unmarried suggest that the married state itself may directly affect mortality. However, the available data are not sufficient to shed light on the many questions that would have to be answered before reaching an understanding of the complex factors involved in the differing mortalities of the marital classes.

For each of the four marital classes, as can be seen in table 2 , the death rates for men are 
higher than those for women in every age group between 20 and 74 . The largest relative difference in rate between the sexes appears in each age group under 60 for the divorced and then in each age group 60 and over for the single. The smallest difference appears in each age group for the married. The ratio of the rate for divorced men to that for divorcees climbs from 2.2 at ages $25-34$ to 2.9 at ages $45-54$ and declines to 1.6 at ages 70-74. The ratio of the rate for bachelors to that for spinsters rises from 1.6 at ages 25-34 to 2.6 at ages 55-59 and then falls to 1.9 at ages 70-74. From 25 to 64 years, in each age group, the rate for widowers is close to double that for widows, and then it declines to 1.5 times at ages 70-74. The death rate for husbands is 1.4 times that for wives at ages 25-34 and 35-44, increases to 1.7 times at ages 55-59, and drops back to 1.4 times at ages 70-74.

\section{A Look Back at 1940}

In the United States, more people than ever before are married. In 1890, the earliest year Federal census figures are available for marital status (2), 2 out of 3 persons 20 years or older were married. By 1950 this proportion had increased to 3 out of 4 . The big jump in the percentage married came in the last 10 yearsfrom 68.8 percent in 1940 to 74.2 in 1950 . For comparison, the percentage distributions by marital status of the male and female populations 20 years and over are given for 1940 and 1950.

\begin{tabular}{|c|c|c|c|c|}
\hline & \multicolumn{2}{|c|}{ Male } & \multicolumn{2}{|c|}{ Female } \\
\hline & 1950 & 1940 & 1950 & 1940 \\
\hline $\begin{array}{l}\text { Single } \\
\text { Married } \\
\text { Widowed } \\
\text { Divorced } \ldots \ldots\end{array}$ & $\begin{aligned} \text { 17. } 0 \\
\text { 76. } 1 \\
\text { 4. } 7 \\
\text { 2. } 2\end{aligned}$ & $\begin{array}{r}\text { 23. } 9 \\
\text { 69. } 7 \\
\text { 5. } 0 \\
\text { 1. } 4\end{array}$ & $\begin{array}{r}11.8 \\
72.3 \\
13.3 \\
2.7\end{array}$ & $\begin{array}{r}\text { 17. } 0 \\
68.0 \\
13.2 \\
1.9\end{array}$ \\
\hline
\end{tabular}

Among both men and women, with few exceptions, in each 5-year age group from 20 to 84 years, the percent single and percent widowed decreased, and the percent married and the percent divorced increased between 1940 and 1950.

The mortality by marital status for the United States in 1940 based on the 1940 census has been published (1). In the 10 years since 1940 there has been a marked decrease in death rate for both men and women at every age. The number of deaths expected in the standard population aged 20 and over-computed in the same manner as described on page 248-decreased a seventh for men and a fourth for women. The percent changes in expected

Table 2. Death rates by marital status, age, and sex; United States, 3-year average, $1949-51$

(Exclusive of deaths among armed forces overseas. Rates per 1,000 population in each specified group enumerated as of April 1, 1950.)

\begin{tabular}{|c|c|c|c|c|c|c|c|c|c|c|}
\hline \multirow{2}{*}{ Age (in years) } & \multicolumn{5}{|c|}{ Male } & \multicolumn{5}{|c|}{ Female } \\
\hline & Total 1 & Single & $\begin{array}{l}\text { Mar- } \\
\text { ried }\end{array}$ & $\begin{array}{l}\text { Wid- } \\
\text { owed }\end{array}$ & $\begin{array}{c}\text { Di- } \\
\text { vorced }\end{array}$ & Total 1 & Single & $\begin{array}{l}\text { Mar- } \\
\text { ried }\end{array}$ & $\begin{array}{l}\text { Wid- } \\
\text { owed }\end{array}$ & $\begin{array}{c}\text { Di- } \\
\text { vorced }\end{array}$ \\
\hline $\begin{array}{l}\text { All ages }{ }^{2} \\
\text { Under } 20^{3} \\
20-24 \\
25-34 \\
35-44\end{array}$ & $\begin{array}{r}11.1 \\
3.4 \\
1.9 \\
2.2 \\
4.3\end{array}$ & $\begin{array}{l}\text { 5. } 4 \\
\text { 3. } 4 \\
\text { 2. } 2 \\
\text { 3. } 6 \\
\text { 8. } 5\end{array}$ & $\begin{array}{r}\text { 12. } 1 \\
\text { 1. } 6 \\
1.5 \\
1.7 \\
\text { 3. } 6\end{array}$ & $\begin{array}{r}\text { 70. } 5 \\
2.0 \\
\text { 5. } 7 \\
\text { 8. } 6 \\
\text { 12. } 1\end{array}$ & $\begin{array}{r}26.1 \\
2.3 \\
\text { 3. } 4 \\
\text { 5. } 8 \\
11.8\end{array}$ & $\begin{array}{l}\text { 8. } 3 \\
2.5 \\
\text { 1. } 0 \\
\text { 1. } 4 \\
\text { 2. } 9\end{array}$ & $\begin{array}{l}\text { 3. } 9 \\
\text { 2. } 6 \\
\text { 1. } 2 \\
\text { 2. } 2 \\
\text { 3. } 9\end{array}$ & $\begin{array}{l}\text { 5. } 8 \\
1.0 \\
.9 \\
1.2 \\
2.6\end{array}$ & $\begin{array}{r}\text { 41. } 1 \\
\text { 4. } 8 \\
\text { 3. } 4 \\
\text { 4. } 1 \\
\text { 6. } 2\end{array}$ & $\begin{array}{l}8.8 \\
1.6 \\
1.7 \\
2.6 \\
4.5\end{array}$ \\
\hline $\begin{array}{l}\mathbf{4 5}-54 \\
\mathbf{5 5}-59 \\
\mathbf{6 0}-64 \\
\mathbf{6 5}-69\end{array}$ & $\begin{array}{l}10.7 \\
20.0 \\
29.0 \\
41.1\end{array}$ & $\begin{array}{l}\text { 17. } 8 \\
\text { 30. } 0 \\
41.0 \\
55.0\end{array}$ & $\begin{array}{r}9.3 \\
17.8 \\
25.8 \\
36.5\end{array}$ & $\begin{array}{l}\text { 21. } 6 \\
\text { 30. } 4 \\
\text { 39. } 5 \\
\text { 50. } 0\end{array}$ & $\begin{array}{l}\text { 23. } 2 \\
\text { 36. } 5 \\
\text { 48. } 6 \\
66.1\end{array}$ & $\begin{array}{r}6.5 \\
11.4 \\
17.5 \\
26.0\end{array}$ & $\begin{array}{r}\text { 7. } 0 \\
11.5 \\
16.6 \\
24.8\end{array}$ & $\begin{array}{r}\text { 5. } 7 \\
\text { 10. } 2 \\
\text { 15. } 7 \\
\text { 23. } 5\end{array}$ & $\begin{array}{l}\text { 10. } 3 \\
14.8 \\
20.7 \\
28.1\end{array}$ & $\begin{array}{r}\text { 9. } 1 \\
\text { 13. } 8 \\
\text { 21. } 1 \\
\text { 33. } 1\end{array}$ \\
\hline 75 and over & $\begin{array}{r}60.4 \\
119.4\end{array}$ & $\begin{array}{r}78.8 \\
137.3\end{array}$ & $\begin{array}{r}\text { 54. } 3 \\
100.3\end{array}$ & $\begin{array}{r}69.1 \\
139.0\end{array}$ & $\begin{array}{r}91.9 \\
173.3\end{array}$ & $\begin{array}{r}\text { 43. } 2 \\
101.6\end{array}$ & $\begin{array}{r}42.3 \\
103.6\end{array}$ & $\begin{array}{l}\text { 39. } 0 \\
\text { 76. } 0\end{array}$ & $\begin{array}{r}44.8 \\
106.2\end{array}$ & $\begin{array}{r}58.2 \\
129.2\end{array}$ \\
\hline
\end{tabular}

1 Includes deaths for which marital status was not stated.

2 Includes deaths for which age was not stated.

3 Rates for "Total" and "Single" are based on deaths and population at ages 0-19 years. Rates for "Married," "Widowed," and "Divorced" are based on deaths and population at ages 15-19 years. 
Age-specific death rates for each marital-sex class as percentages of death rates for married persons of corresponding age and sex; United States, 3-year average, 1949-51.



deaths from 1940 to $1949-51$ by marital status were:

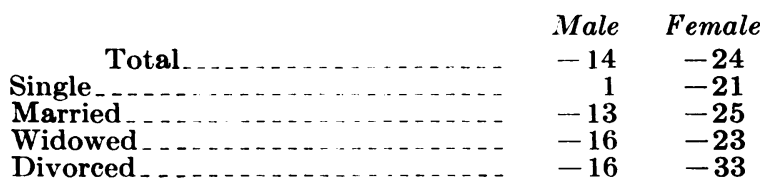

All but one of the marital-sex classes benefited from the improvement in mortality conditions. Expected deaths for bachelors were about the same in 1949-51 as 10 years ago.

Comparison of the age-specific death rates for 1940 with those for 1949-51 by marital status and sex shows that, except for bachelors, declines were recorded for each marital-sex class at all ages. The percentage changes in death rates between 1940 and $1949-51$ are shown in table 3.

Between the two periods, the death rate for women dropped about one-fifth or more for each age group in each marital class, with the greatest drops recorded for the youngest years. At ages 20-34 the rates for wives were cut in half. The death rates for the married, widowed, and divorced men were lower at every age in 1949-51 than in 1940, with the greatest decreases, about a third, recorded for ages under 35. Middle-aged and elderly bachelors did not share in the general mortality improvement of the 10year period.

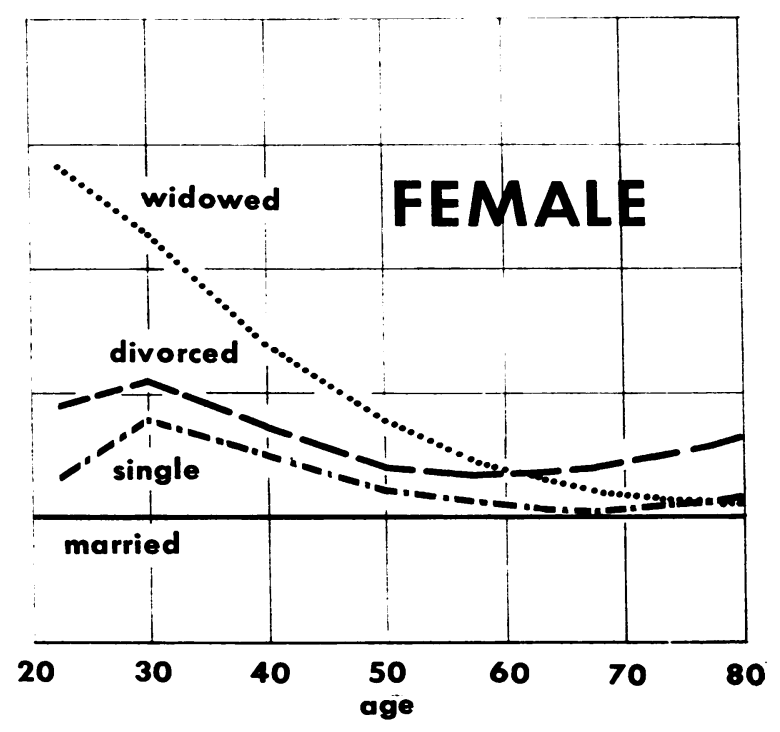

The changes in mortality among the marital classes since 1940 can also be seen by comparing the summary measures for 1940 with those for 1949-51 previously described. The 1940 percentages relating the expected number of deaths of each marital-sex class to the expected num-

Table 3. Percentage changes in death rates between 1940 and 1949-51, by marital status, age, and sex: United States

\begin{tabular}{|c|c|c|c|c|}
\hline $\begin{array}{l}\text { Sex and age } \\
\text { (in years) }\end{array}$ & Single & Married & Widowed I & Divorced \\
\hline Male & & & & \\
\hline $\begin{array}{l}20-24 \\
25-34 \\
35-44 \\
45-54 \\
55-59 \\
60-64 \\
65-69 \\
70-74 \\
75 \text { and over }\end{array}$ & $\begin{array}{r}-24 \\
-23 \\
-8 \\
2 \\
5 \\
7 \\
5 \\
5 \\
4\end{array}$ & \begin{tabular}{r|}
-32 \\
-35 \\
-25 \\
-12 \\
-7 \\
-7 \\
-7 \\
-10 \\
-12
\end{tabular} & $\begin{array}{r}-52 \\
-25 \\
-14 \\
-9 \\
-13 \\
-8 \\
-13 \\
-13 \\
-14\end{array}$ & $\begin{array}{r}-38 \\
-31 \\
-17 \\
-12 \\
-7 \\
-8 \\
-10 \\
-20 \\
-19\end{array}$ \\
\hline Female & & & & \\
\hline $\begin{array}{l}20-24 \\
25-34 \\
35-44 \\
45-54 \\
55-59 \\
60-64 \\
65-69 \\
70-74 \\
75 \text { and over }\end{array}$ & $\begin{array}{l}-40 \\
-29 \\
-19 \\
-20 \\
-23 \\
-24 \\
-24 \\
-19 \\
-18\end{array}$ & $\begin{array}{l}-57 \\
-52 \\
-37 \\
-27 \\
-24 \\
-21 \\
-23 \\
-21 \\
-18\end{array}$ & $\begin{array}{l}-47 \\
-39 \\
-22 \\
-18 \\
-20 \\
-19 \\
-22 \\
-21 \\
-17\end{array}$ & $\begin{array}{l}-53 \\
-35 \\
-29 \\
-30 \\
-28 \\
-29 \\
-31 \\
-34 \\
-35\end{array}$ \\
\hline
\end{tabular}


ber of deaths of married persons of the same sex are:

\begin{tabular}{|c|c|c|}
\hline & \multicolumn{2}{|c|}{ Single Married Widowed Divorced } \\
\hline $\begin{array}{l}\text { Male } \\
\text { Gemale. }\end{array}$ & $\begin{array}{l}141 \\
117\end{array}$ & $\begin{array}{l}100 \\
100\end{array}$ \\
\hline
\end{tabular}

The relative mortality of the marital classes did not change in the decade following 1940the lowest mortality was for the married population, the next for the single group, and the highest among the widowed and divorced-but the percentage excesses in the mortality of the unmarried compared with the married shifted somewhat. The excess in the mortality of bachelors over that of husbands is 41 percent for 1940 and 63 percent for 1949-51. The excess in the mortality of spinsters over that of wives is 17 percent for 1940 and 24 percent for 1949 51. The corresponding excesses in mortality of divorced persons and of widowers are smaller in 1949-51 than in 1940; the excesses in mortality of widows are about the same in the two periods. Such changes have probably resulted from changing factors influencing marital status as well as mortality.

\section{Summary}

Imong both men and women at every age, the married have lower death rates than the single, widowed, or divorced. When allowance is made for the variation in age distribution, the mortality of bachelors is nearly two-thirds greater than that of husbands, and the mortality of widowed and divorced men is about double that of husbands. The differences are not as large for women. The mortality of spinsters is a fourth again as high as that of wives, while the mortality of widows and divorcees is half again as high. The available data do not afford an interpretation of the nature of selection of persons into the marital groups, and the effect of - marriage itself on mortality rates.

\section{REFERENCES}

(1) U. S. Bureau of the Census: Mortality by marital status by age, race, and sex, urban and rural, United States, 1940, Vital Statistics-Special Reports, vol. 23, No. 2, 1945.

(2) U. S. Bureau of the Census: U. S. Census of Population, 1950, vol. 2. Characteristics of the Population. Part 1. United States Summary. Washington, I. C.. U. S. Government Printing Office, 1953.

\section{Home Safety Booklet Available}

An 8-page booklet, entitled "Home Safety Principles," has been prepared from copy published by the National Association of Home Builders in cooperation with the National Safety Council and the Public Health Service in the magazine, Practical Builder.

The principles enumerated in this booklet cover general construction and safety inside and outside the house. Specific attention is given to safety matters in the yard, the exterior of the house and garage, roof and chimney, crawl space, kitchen, living, dining and bedrooms, bathroom, closets and storage space, electrical, plumbing, heating, and air conditioning systems. The booklet also features a home safety check list.

Most of the principles can be applied with little or no additional cost. If followed, they should contribute significantly to the reduction of accidental home injuries and deaths.

Copies of the reprint are available from the Division of Engineering Services, Bureau of State Services, Public Health Service, Washington 25, D. C. 